\title{
Crop Model Simulation Slants for Predicting and Managing the Climate Risks in Poor Rainfed Rice-Wheat Eco-System of Mid-Western Nepal: Application of APSIM, DSSAT Model and Trade off Economic Analysis
}

\author{
Rajendra Darai ${ }^{*}$, Dinesh Babu Thapa Magar ${ }^{2}$, Natraj Subash ${ }^{3}$ and Guillermo Baigorria ${ }^{4}$ \\ ${ }^{1}$ Senior Scientist, NARC/GLRP, Nepalgunj and Co-PI-IGB, Nepal \\ ${ }^{2}$ Scientist, SARPOD, NARI, Khumaltar, Nepal \\ ${ }^{3}$ Senior Scientist - IGB Team Leader, ICAR, Farming system Directorate, Meerut, India \\ ${ }^{4}$ Professor and Climatologist University of Nebraska, Lincoln, USA \\ *Corresponding Author: Rajendra Darai, Senior Scientist, NARC/GLRP, Nepalgunj and Co-PI-IGB, Nepal.
}

Received: April 29, 2019; Published: August 28, 2019

DOI: $10.31080 /$ ASAG.2019.03.0633

\begin{abstract}
The Agriculture is the life line of Nepalese people which contributes to more than $34 \%$ GDP and employing > 65\% of total population. In Nepal, agriculture sector is in small fragmented subsistence rainfed farming system, must therefore be a special area of plan focus on other priorities such as resource use efficiency and technology to ensure sustainability of natural resources, adaptation to climate change and improvements in total factor productivity. Obviously Nepalgunj, Banke district is the hub for mid and far western development region of Nepal. Whatsoever it is the hottest place of Nepal with temperature rising well above $46^{\circ} \mathrm{C}$ in the summer, while minimum temperature goes down to $5^{\circ} \mathrm{C}$ or even below during the winter season. Annual average rainfall ranges from $1000 \mathrm{~mm}$ to $1500 \mathrm{~mm}$ in the district. The rice-wheat cropping system is currently practiced on about 0.5 million hectare of prime agricultural land in terai and lower basin of mid hills of Nepal. Both of the crops are grown in diverse agro-ecological environments and also seasonal diversity (rice-summer and wheat-winter) from terai to hills. All five GCMs predicted higher mean monthly maximum and minimum temperatures during the mid-century period (2040-2069) under RCP8.5 compared to the baseline (1980-2010). However, rainfall projections are reduction trends in all GCM predictions except GCM IIXA. Both APSIM and DSSAT simulated higher wheat and rice yields compared to survey data after the cumulative probability level except one GCM. Moreover, DSSAT simulated higher rice yields than did APSIM. Differences between the DSSAT and APSIM projections are due to differences in sensitivity of the crop models to increases in $\mathrm{CO} 2$ and temperature. In the case of rice, out of the $20 \mathrm{GCMs}$ there is an $80 \%$ positive response both in DSSAT-rice and wheat projected a pessimistic scenario. Overall, DSSAT simulated more optimistic projections than APSIM for wheat. The integrated assessment result in DSSAT showed that mean yield of wheat crop in the future period would decline from 5\% to $33 \%$ than the historic or base period. APSIM simulation also showed similar results for wheat with declining yield from $14 \%$ to $18 \%$ in the tested climate scenarios. APSIM simulation interestingly also showed $18 \%$ yield decline in rice crop in the future period in GFDL ESM2M scenario. While for the mixed crops (include crops like maize, lentil, chickpea, pigeon pea, mustard, and vegetables) an assumption was made that it would decline by $15 \%$ in all the climate scenarios in the future period. Overall, the simulation results showed that the mean net farm returns would decline by $14 \%$ to $16 \%$ in DSSAT and $14 \%$ to $24 \%$ in APSIM in the tested climate scenarios. The simulation results in different climate scenarios have shown mixed results in per capita income (PCI), net farm returns and poverty rate. Both the crop model simulations (DSSAT and APSIM) have shown higher PCI, net farm returns and reduction in poverty in the future period in those scenarios where increase in rice yield is higher than decrease in wheat yield in future than the base period and vice versa. The results showed a very small difference (less than 1\%) in the poverty rate in between future and current period. DSSAT simulation has shown higher percentage of gainers (farm populations gaining in future period) in HadGEM2-ES, MIROC5, and MPI-ESM-MR scenarios while APSIM simulation has shown higher percentage of gainers CCSM4 and MIROC5 scenarios. Both the crop model simulations have shown higher percentage of losers in GFDL ESM2M scenario. Various RAP parameters and other estimates
\end{abstract}


of productivity and price trends from a global model (IMPACT model) for rice and wheat crop and assumption of similar changes in yield and price of mixed crop was used in the TOA-MD analysis for assessing the impacts of climate change on future agricultural production systems. The simulation results have shown increasing yield of rice crop and declining yield of wheat crop and mixed crops in the future period than the base period. However, due to changes in the socio-economic parameters (increased output price), the simulation results have shown higher net farm returns, per capita income and reduction in poverty rate in all the tested scenarios in the future period except in GFDL ESM2M scenario where DSSAT simulation results has shown decreasing net farm returns, per capita and income and slightly increased poverty rate in the future period than the base period. The simulation results showed both positive and negative effect of climate change to the rice and wheat crop yield respectively. Therefore, adaptation strategy was applied only for the wheat crop and advancement of seed sowing by 20 days was the key adaptation strategy applied to compensate the loss due to climate change. DSSAT simulation results showed increase of wheat yield by $21 \%$ to $55 \%$ while APSIM showed $1 \%$ to $39 \%$ yield gain by adopting this adaptation strategy in wheat. The adaptation strategy is likely to result in an increase of mean net farm returns, per capita income and reduce the poverty rate of the farming population considerably.

Conclusion: The next steps would be sharing the results of this study to the stakeholders so that appropriate actions could be taken to reduce the impacts of climate change. Similarly, other adaptation strategies could also be tested to identify and ensure even better adaptation alternatives. Based on the knowledge and skill gained through this study, continuing the similar research incorporating livestock in other locations can also be another important next step.

Keywords: DSSAT; APSIM; Simulation Models; Rice; Wheat; Climate Risks; Cropping Systems; Adaptation Strategy; Trade-Off Economic Analysis

\section{Introduction}

Regional agricultural systems and climate-change challenges

The Agriculture is the life of Nepalese people and the agriculture sector is the main stay of Nepalese people which solely contributes to more than 34 percent Nepal's Gross Domestic Products (GDP) and employing more than 65 percent of its total population [1]. In Nepal, agriculture sector is in small fragmented subsistence farming system, must therefore be a special area of Plan focus on other priorities such as resource use efficiency and technology to ensure sustainability of natural resources, adaptation to climate change and improvements in total factor productivity. It was reported that only 21 per cent of Nepal's land is cultivable. The country is mainly dominated by rainfed agriculture, and only 33 per cent of the cultivated land has irrigation facility. Nepalgunj, Banke district is hub for one of the terai districts of Nepal. It lies in the mid-western development region of Nepal and borders with Bahraich district, Uttar Pradesh State of India in the south. Nepalgunj is the hottest place of Nepal with temperature rising well above $46^{\circ} \mathrm{C}$ in the summer, while minimum temperature goes down to $5^{\circ} \mathrm{C}$ or even below during the winter season. Annual average rainfall ranges from $1000 \mathrm{~mm}$ to $1500 \mathrm{~mm}$ in the district. Rice-wheat based farming system is the dominant farming system in the terai or plain areas of Nepal. Rice, wheat and maize are the major cereal crops grown in the district. Apart from that farmers also grow other crops like grain legumes (lentil, chick pea, pigeon pea, cow pea, mungbean), oil seed (mustard, linseed), vegetables and tropical fruits. Due to poor irrigation facilities in the district, most of the agricultural land remains fallow during the spring season. Farmers also raise livestock such as cattle, buffalo, goat, pigs and poultry; mostly at subsistence level. The farmers use crop residues for livestock feeding while manure and draft is obtained through the livestock for growing crops. Similarly, farmers obtain milk, meat and income from the livestock. Therefore, the majority of the farmers still rely on rainwater for irrigation. Now these sectors are prone to more vulnerable due to climate change. Climate change and agriculture are interrelated processes, both of which take place on a global scale. Climate change is a phenomenon due to emissions of greenhouse gases from fuel combustion, deforestation, puddles cultivation, urbanization and industrialization (Upreti, 1999) resulting variations in solar energy, temperature and precipitation. Agricultural production has directly negative impacts and increase the people's vulnerability due to the natural disasters like floods, droughts, landslides, erratic rainfalls pattern, hailstorms, rising temperature and cold and heat waves. Recently mega earthquake 7.8 magnitude epicentre Gorkha in Nepal and it's continue hits trend (4-5.2 rector) devastated many human lives, lost the villages, cities, pilgrim places and most importantly agricultural lands if 
consider it the part of climate change. Such climate change -related events have put fragile agricultural ecosystems at risk. Climate change is likely to alter the balance between insect pests, their natural enemies and their hosts. Increase in temperature and $\mathrm{CO}_{2}$ will lead to an increase in population of pests and severity of diseases in presence of host plant. It increases the rate of reproductive cycle of insect and pest. Pests and diseases of plain ecosystems may gradually shift to hills and mountains. 19 Some pathogens of important crops from the Terai zone has adapted in hills and midhills (rust and foliar blight) that may affect the agricultural production. In Nepal, the witness of climate change is the new disease emerging observed in leguminous crops i.e. Stemphylium blight in lentil and Hallo blight in phaseolus bean and more insects incidences i.e. army worm, sucking bugs in soybean, blackgram etc which reduces the crop yields substantially. These are the evidences of negative impacts of climate change which often lead to food insecurity for poor, disadvantage and marginalized populations, including women and children. Those communities who are residing in the rural areas and absolute dependent on the natural resources are in high risk. Despite its relatively small land locked country, Nepal has very diverse climatic conditions, ranging from tropical in the south to alpine in the north. The country's three distinct geographies-the snow covered mountains, the mid hills and the tarai (plains) embodies this diversity. Its hydrology is fed largely by the South Asian monsoon system (SAM), but the relationship between the timing, volume of monsoon rainfall and the mountain landscape is poorly understood. The results of global climate scenario modeling suggest that the impacts of climate change may be intense at high elevations and in regions with complex topography, as is the case in Nepal's mid-hills. More than a decade ago preliminary analysis by Mirza and Dixit (1997) found that climate change in the Ganga and Brahmaputra basins is likely to change river flows, which in turn will affect low flows, drought, flood and sedimentation processes. In 1999 Shrestha., et al. suggested that temperatures are increasing in Nepal and that rainfall is becoming more variable. A decade later, in 2009, a modeling exercise conducted by team of Nepali, American, British, Pakistani and Bangladeshi experts (NCVST, 2009) using the emissions scenarios in the IPCC's special report (2007) found that the temperature will indeed increase in the mid-hills and that this region is likely to grow more arid in the non-monsoon seasons. It also suggested that precipitation is likely to be more uncertain and that storm intensity will increase. Global circulation model (GCM) projections indicate that the temperature over Nepal will increase between $0.5^{\circ} \mathrm{C}$ and $2.0^{\circ} \mathrm{C}$ with a multi-model mean of $1.4^{\circ} \mathrm{C}$, by the $2030 \mathrm{~s}$ and between $3.0^{\circ} \mathrm{C}$ and $6.3^{\circ} \mathrm{C}$, with a multi-model mean of $4.7^{\circ} \mathrm{C}$, by the $2090 \mathrm{~s}$.
GCM outputs suggest that extremely hot days (the hottest 5\% of days in the period from 1970 to 1999) are projected to increase by up to $55 \%$ by the 2060 s and up to $70 \%$ by the 2090 s. GCM outputs suggest that extremely hot nights (the hottest $5 \%$ of nights in the period from 1970 to 1999) are projected to increase by up to $77 \%$ by the 2060 s and $93 \%$ by the 2090 s.GCMs project a wide range of precipitation changes, especially during the monsoon: from a decrease of $14 \%$ to an increase of $40 \%$ by the 2030 s and from a decrease of $52 \%$ to an increase of $135 \%$ by the 2090s. Higher temperatures eventually reduce yields of desirable crops while encouraging weed and pest proliferation. Changes in precipitation patterns increase the likelihood of short-run crop failures and longrun production declines. Although there will be gains in some crops in some regions of the world, the overall impacts of climate change on agriculture are expected to be negative, threatening global food security. In developing countries like Nepal, climate change will cause yield declines for the most important crops. South Asia will be particularly hard hit. Climate change will have varying effects on irrigated yields across regions, but irrigated yields for all crops in South Asia will experience large declines. Effect of changing temperatures and erratic rainfall pattern on crop and livestock production has been observed in Nepal (MoE, 2010). Various study reports have indicated that compared to pre-2000 baseline, there will be increase in mean annual temperature by an average of $1.2^{\circ}-1.4^{\circ} \mathrm{C}$ by $2030,1.7^{\circ} \mathrm{C}-2.8^{\circ} \mathrm{C}$ by $2050-60$ and $3^{\circ} \mathrm{C}-4^{\circ} \mathrm{C}$ by $2090-2100$. Similarly precipitation is projected to be increased by $15 \%$ to $20 \%$ for the whole country with increase in monsoon and post-monsoon rainfall (particularly in eastern and central Nepal) as well as an increase in the intensity of rainfall, and a decrease in winter precipitation in the country (NCVST, 2009; OECD, 2003; FAO, 2010). Climate change will result in additional price increases for the most important agricultural crops-rice, wheat, maize, and soybeans. Higher feed prices will result in higher meat prices. As a result, climate change will reduce the growth in meat consumption slightly and cause a more substantial fall in cereals consumption. Calorie availability in 2050 will not only be lower than in the no-climatechange scenario-it will actually decline relative to 2000 levels throughout the developing world. By 2050, the decline in calorie availability will increase child malnutrition by 20 percent relative to a world with no climate change. Climate change will eliminate much of the improvement in child malnourishment levels that would occur with no climate change. Thus, aggressive agricultural productivity investments of US\$7.1-7.3 billion2 are needed to raise calorie consumption enough to offset the negative impacts of climate change on the health and well-being of children $[2,3]$. 
Nepalgunj is the headquarters of Banke district and in fact it is the hub sub-metropolitan city of mid and far western development region. Banke district is one of the terai districts of Nepal and is bordered on the west by Bardiya district. Rapti zone's Salyan and Dang Deukhuri Districts border to the north and east. To the south lie Uttar Pradesh, India; specifically Shravasti and Bah- raich districts of Awadh. East of Nepalganj the international border follows the southern edge of the Dudhwa Range of the Siwaliks. Most of the district is drained by the Rapti, except the district's western edge is drained by the Babai. Rapti and Babai cross into Uttar Pradesh, India and eventually join the Karnali, whose name has changed to Ghaghara.

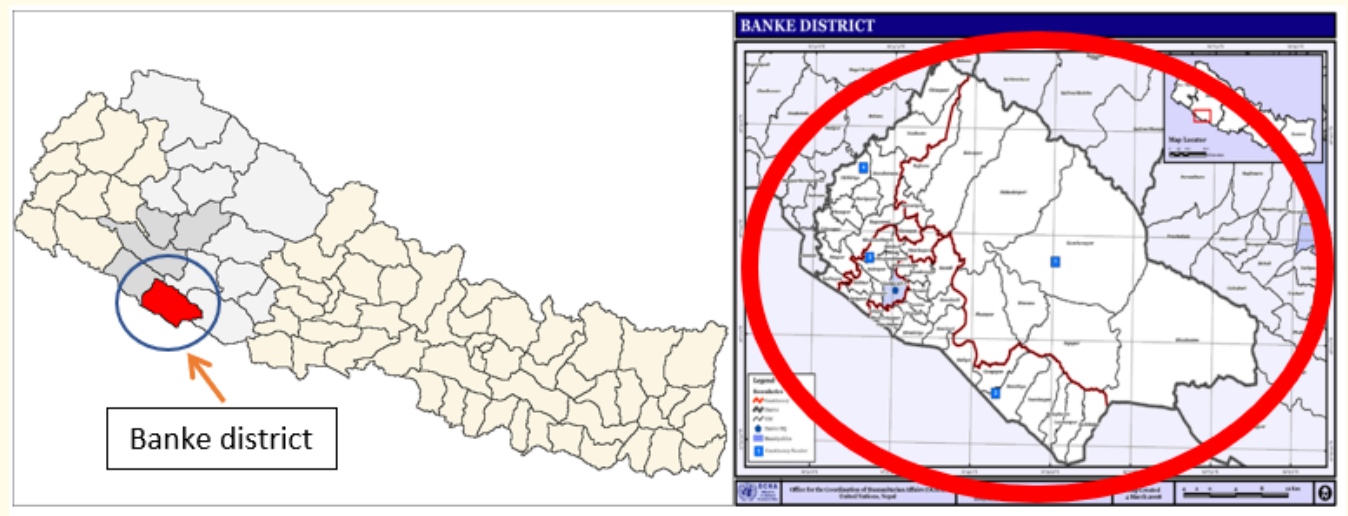

Figure 1: The location of the study site in Nepalgunj, Banke district, Mid-western terai of Nepal.

Nepal is highly vulnerable to climate change and managing agricultural risk associated with climate change and climate change adaptation is very challenging for the country (MoE, 2010). Ricewheat, the intensively grown system in Nepal has caused rapid depletion of soil fertility. Consequently the productivity of the crops is quite low due to the imbalance use of fertilizers, organic manures and inappropriate practices. Several crop model have been successfully evaluated and applied for wheat in north-west India (Timsina and Humphreys, 2006; Timsina., et al 2008; Jalota and Arora, 2006; Jalota., et al. 2006).

\section{Description of farming system investigated}

\section{Settings and locations}

The study area is located at Nepalgunj, Banke district $\left(81^{\circ} 37^{\prime} \mathrm{E}\right.$ longitudes, $28^{\circ} 6^{\prime} \mathrm{N}$ latitude and $181 \mathrm{msl}$ altitudes) VDCs namely Puraina $\left(28^{\circ} 2^{\prime} 24^{\prime \prime} \mathrm{N}, 81^{\circ} 39^{\prime} 36^{\prime \prime} \mathrm{E}\right)$ and This study used a secondary survey data which was conducted in drought prone Samshergunj (28 $29^{\prime} 36^{\prime \prime} \mathrm{N}, 81^{\circ} 39^{\prime} 36^{\prime \prime} \mathrm{E}$ ) of the district. Through the AgMIP -IGB team, the site was also considered as the upper part of Indo-gangetic plains (IGB), Nepal.

\section{Climate and soil data}

The climate is sub-tropical having the hot and dry summer and extremely cold winter. At this place, temperature rising above $46^{\circ} \mathrm{C}$ in the summer (April-June) and it sometimes is foggy and overcast; then it can be chilly with minimum temperatures goes down to $3^{\circ} \mathrm{C}$ or even below but no frost during the winter season. Relative humidity (R.H.) of the district has ranging between 27 to $94 \%$. Humidity remains low in most parts of the year. Annual average rainfall ranges from $1000 \mathrm{~mm}$ to $1500 \mathrm{~mm}$ in the district but often erratic rainfall occurs and more than $85 \%$ of the rainfall occurs from June to September. The monsoon starts generally late $2^{\text {nd }}$ fortnight of June and terminates earlier $2^{\text {nd }}$ fortnight of September. Meteorological data were collected from the agro-meteorological observatory located at the Regional Agricultural Research Station, Khajura, Nepalgunj and from Department of Hydrology and Meteorology (DHM), Kathmanduto the experimental site, during the period 1980-2010. Data collected include daily maximum and minimum temperatures, rainfall, and sunshine hours. The solar radiation $(\mathrm{Mj} / \mathrm{m} 2 /$ day) was downloaded via the internet from the National Aeronautics and Space Administration (NASA) (Perry Poulton, 2012). The climate data for the period 1980-2009 were created using the bias-corrected AgMERRA (Modern-Era Retrospective Analysis for Research and Applications, Ruane., et al. 2014) satellite-derived data. The climatic scenarios for 20 global climate models (GCMs) were generated through the R-codes provided by AgMIP (Ruane and Hudson, 2013). These climate data has been used for the scenario analysis. Likely a household survey data received from SARPOD, Khumaltar has also been obtained and used for the crop and economic modelling analysis. 
The soil of the experimental site is a sandy to silty loam soil, poor in organic carbon and available $\mathrm{N}$, but medium in available $\mathrm{K}_{2} \mathrm{O}$ and $\mathrm{P}_{2} \mathrm{O}_{5}$ having slightly alkaline soil reaction ( $\mathrm{pH}$ 7.2-7.5). Soil physical and chemical characteristics data (viz., bulk density, electrical conductivity, $\mathrm{pH}$, organic carbon, ammonical nitrogen and nitrate nitrogen) were determined for different depths $(0-15,15-$ 30, 30-50, 50-80 and 80-110 cm). Soil Science Division of Nepal Agricultural Research Council (NARC), Khumaltar, Lalitpur provided the soil analysis report of experimental site. Soil texture, field capacity (drained upper limit), and 15-bar lower limit at different depths were also determined.

\section{Farming system diagram}

The Rice-wheat cropping system covers an estimated area of 13.5 million hectares in Indo-Gangetic plains in south Asia, consisting of Bangladesh, India, Nepal and Pakistan (Ladha., et al. 2003). The system is currently practiced on about 0.5 million hectare of prime agricultural land in terai and lower basin of mid hills of $\mathrm{Ne}$ pal. Rice and wheat covers about $43 \%$ and $22 \%$ area respectively out of the total cereal area 3478813 ha in Nepal (MOAC, 2012).
Both of the crops are grown in diverse agro-ecological environments and also seasonal diversity (rice-summer and wheat-winter) from terai to hills. Rice-wheat farming system is pre-dominant farming system in the terai areas of Nepal. Rice, wheat and maize are the major cereal crops grown in the district. Apart from that farmers also grow other crops like grain legumes (lentil, chickpea, pigeonpea, cowpea, mungbean etc), oil seed (mustard, linseed), vegetables and tropical fruits. Due to poor irrigation facilities in the district, most of the agricultural land remains fallow during the spring season. Farmers also raise livestock such as cattle, buffalo, goat, pigs and poultry; mostly at subsistence level. The farmers use crop residues for livestock feeding while manure and draft is obtained through the livestock for growing crops. Similarly, farmers obtain milk, meat and income from the livestock.

However, in this study we have been considered only the ricewheat farms of each household. The study site has absolute dry land agriculture system where more or less $>90 \%$ rainfed cultivable lands. Farming system diagram existing in the district is given below.

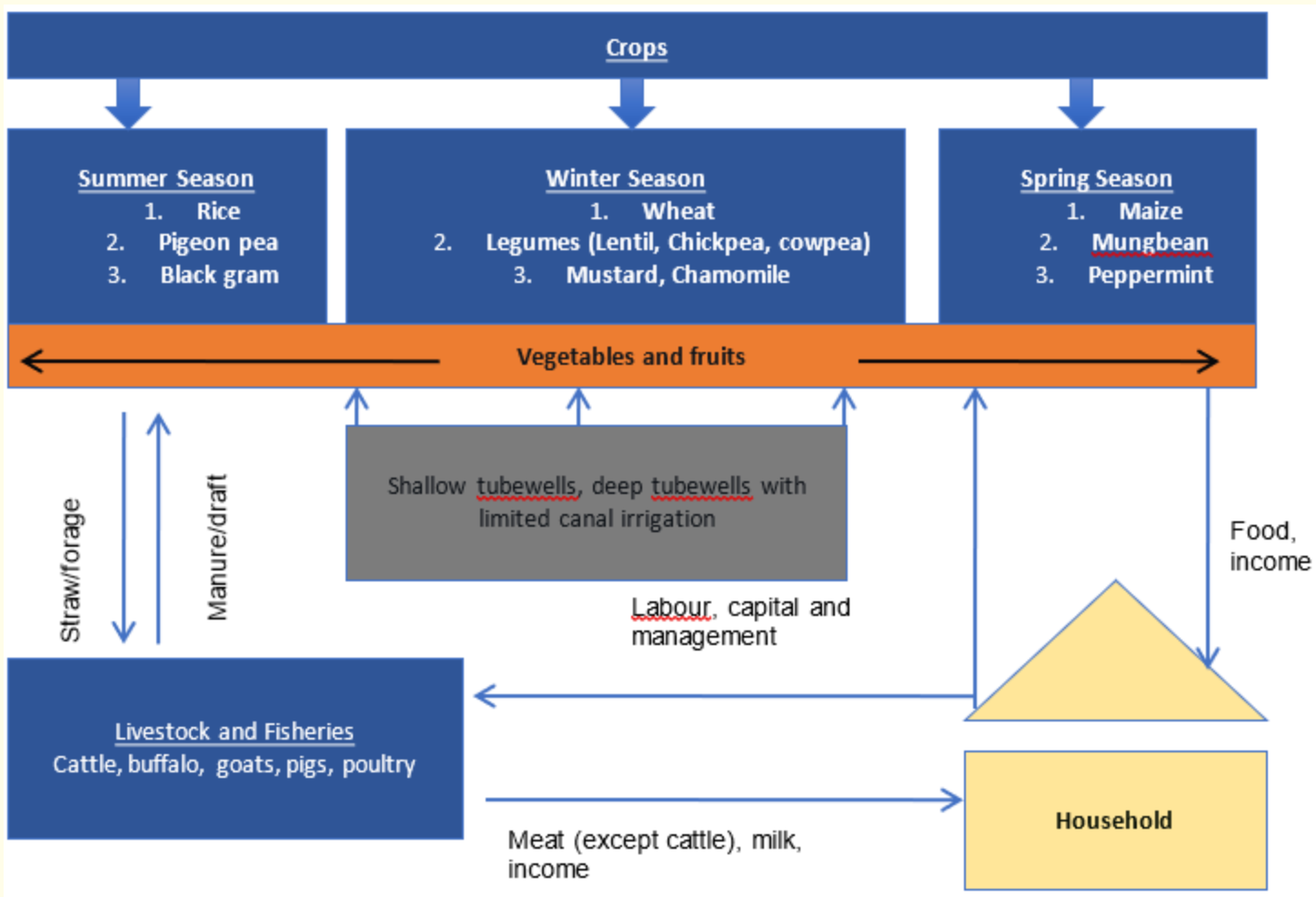

Figure 2: Farming system diagram in Banke district, Nepal. 
Stakeholder interactions, meetings, and representative agricultural pathways

Stakeholder interactions and meetings

Among the different research team of South Asia region, AgMIP- IndoGangetic Basin (IGB) team is also one of the research team which includes the multidisciplinary scientists from three different countries Nepal, India and Bangladesh who are actively involved in climate change impact assessments to their own settings. Nepal Agricultural Research Council (NARC) is one of the implementing partners of Indo Gangetic Basin (IGB) research team and Grain Legume Research Program (GLRP) and SocioEconomics and Agricultural Research Policy Division (SARPOD) through NARC governmental research institution are participated in AgMIP project and studied the impacts of climate change to the agriculture and possible adaptation options to reduce the climate change impacts. Both of the NARC stations have used the secondary data (farmers' household survey data of Banke district-2008) obtained from SARPOD as well as 30 years long-term meteorological data obtained from RARS, Khajura and Department of Hydrology and Meteorology in order to examine the sensitivity of current agricultural production systems to climate change and also used primary information (multidisciplinary scientists and stakeholders feedback) on representative agricultural pathways to assess the climate change impacts on agricultural production system as well as benefits of climate change adaptation in the future. Various stakeholders have been directly or indirectly engaged and also had contribution for this study. Major stakeholders interacted during implementation of this project include Ministry of Agricultural Development, Nepal, NARC and its sci- entists and Department of Agriculture (District Agriculture Development Office) and the extension workers, Department of Environment, Department of Hydrology and Meteorology, Agriculture and Forestry University, Tribhuwan University, Agricultural Inputs Company Limited, Non-governmental organizations, students and farmers. This report summarises their engagement and contribution to conduct this study. As this study is based on both primary and secondary data, various stakeholders were engaged while conducting different activities of this project. The major stakeholders that had actively participated while conducting this study include;

1. Department of Agriculture, Ministry of Agriculture and Development

2. Department of Environment, Ministry of Science, Technology and Environment

3. Department of Hydrology and Meteorology, Ministry of Science, Technology and Environment

4. Different research stations of NARC (SARPOD, NGLRP, RARS/Khajura, Agricultural Environment Division, Soil Science Division, Entomology and Pathology Division, Agri-Engineering Division, Agronomy Division, National Wheat Research Program, National Rice Research Program etc.)

5. Agriculture Inputs Company

6. Non-government offices

7. University Students and PhD scholars

8. Farmers
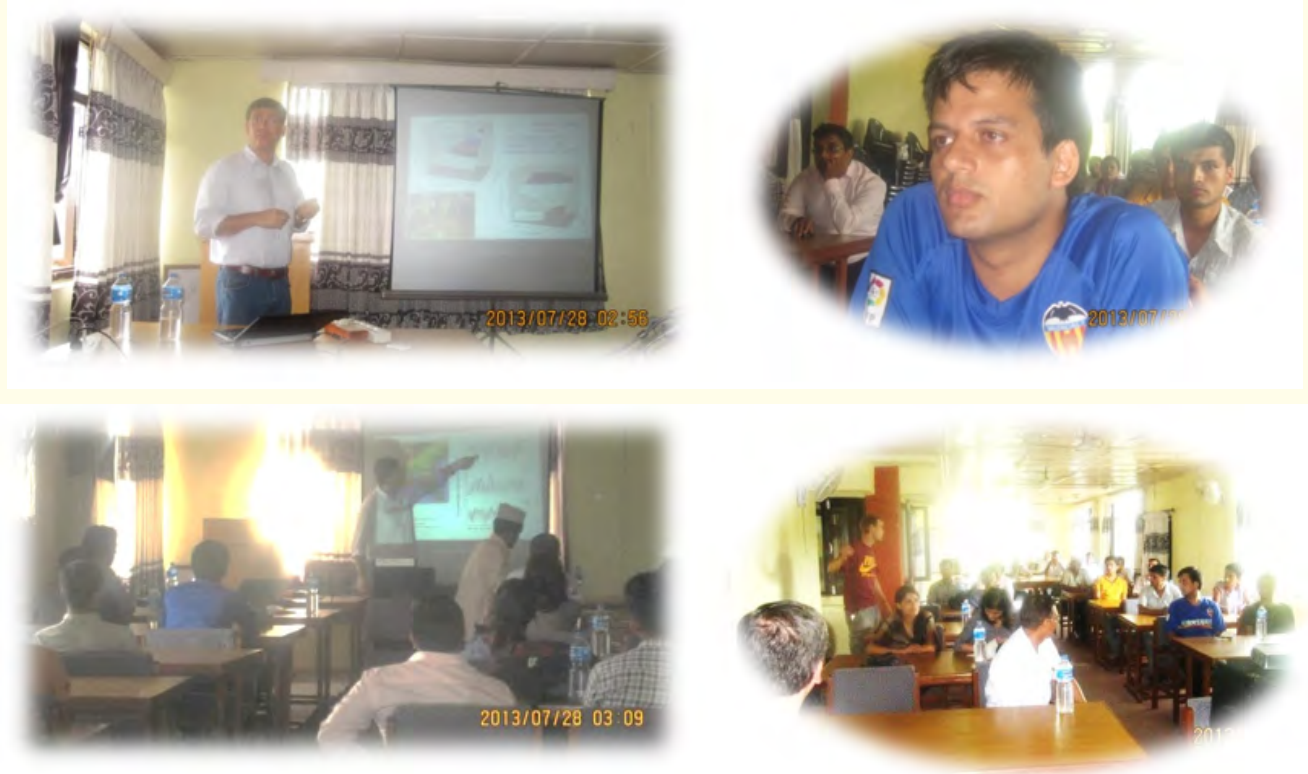

Figure 3: Dr. Guillermo delivered the updated DSSAT modelling and discussed with the stakeholders of Agriculture and Forestry University's Master, PhD Students and NARC's scientists. 

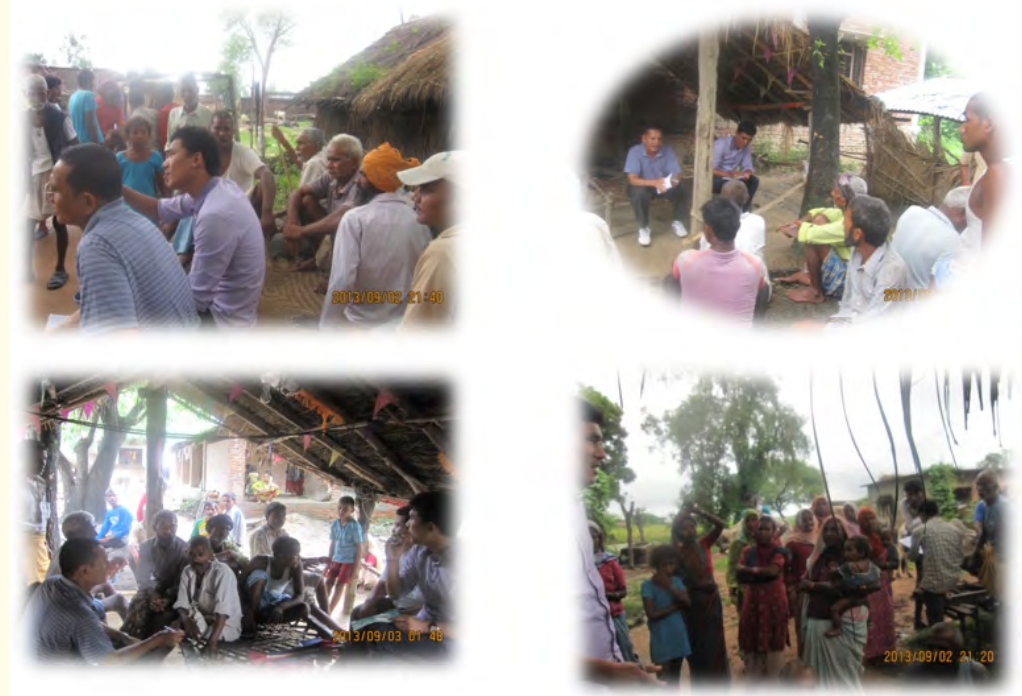

Figure 4: Interaction with the stakeholders' farmers of Banke district.

Representative agricultural pathways (RAPs)

These stakeholders had actively participated to share the information and collate the feedbacks for improving the study. During the implementation period of this project, a considerable support and remarkable inputs have been obtained from the various stakeholders particularly in developing representative agricultural pathways (RAPs) for Nepal. RAPs is one of the important tool to visualize the socio-economic and technological development at global, regional and national level that includes quantitative trends for the variables related to various aspects such as bio-physical, institutional/policy, socio- economic and technological aspects and developing RAPs and using RAP narratives are important to construct scenarios for crop (and livestock) models and for economic models (TOA-MD). Developing RAPs therefore is a trans-disciplinary activity involving collaboration among the stakeholders and experts of various relevant disciplines. This project has also involved the various stakeholders and multidisciplinary experts through workshops, face to face interaction with the experts and stakeholders as well as via other means of communication (telephone and internet) to develop the RAPs and use its narratives for crop and economic analysis. The engagement of stakeholders during the conduction of this research project has been useful in communicating the information about the project to them and also to receive the feedback and information for improving the study. Prices, policy, and productivity trends should be consistent with the higher-level RAPs or scenarios that are available (SSPs, global RAPs, CCAFS regional scenarios). RAPs are translated into one or more scenarios (parameterizations) for TOA-MD (Trade-off Anal- ysis Model for Multi-dimensional Impact Assessment) and crop models. These scenarios represent a set of technology and management adaptations to climate change. These scenarios, developed for specific RAPs, will typically include changes in the types of crops or livestock produced and the way they are managed (e.g. use of fertilizers and improved crop cultivars). Procedures for RAP development are based on the step-wise process as described in Valdivia and Antle (2014). With the inputs and feedbacks obtained from the multidisciplinary experts and stakeholders, the project has become able to develop a draft RAPs and the RAP narratives have also been used in this project. The project till date has been received considerable support from all the stakeholders and also will be involved to support whenever necessary during the RAP developmental process to get the better results of the project.

\section{RAP narratives}

Rainfed dominant and subsistence based agricultural production system of the country would be continuously exposed to climatic variability such as temperature rise, drought, and erratic rainfall. To enable farmers adapt to climate change and enhance agricultural production, the government would assure minimum support price for major agricultural products and subsidies to the agricultural inputs and equipment. Similarly, public investment on agricultural research and development as well as agricultural insurance will be increased. The country will continue to rely on import for the fertilizer supply. There will be large increase in prices of the agricultural inputs such as seed, fertilizers and wage rates of agricultural labors leading to increased cost of production of agricultural commodities and the government subsidies on agricultural 
inputs would help to lower the production cost to a small extent only. There will be increased employment and income opportunities to the people in off-farm activities which will create shortages in agricultural labors, and also shrinkages in land under agricultural operations. Moreover, farm mechanization will be increased to a medium extent which will compensate the labor shortages in agriculture sector. Similarly irrigation services will be extended to a small extent while extension and adoption of improved agricultural technologies (improved varieties and agronomic management practices) will be increased that will help farmers in adapting to climate change and enhancing the agricultural production.

Data and methods of study

Climate

Observed trends in temperature and precipitation

Effect of changing temperatures and erratic rainfall pattern on crop and livestock production has been observed in Nepal (MoE, 2010). Various study reports have indicated that compared to pre2000 baseline, there will be increase in mean annual temperature by an average of $1.2^{\circ}-1.4^{\circ} \mathrm{C}$ by $2030,1.7^{\circ} \mathrm{C}-2.8^{\circ} \mathrm{C}$ by $2050-60$ and $3^{\circ} \mathrm{C}-4^{\circ} \mathrm{C}$ by $2090-2100$. Similarly precipitation is projected to be increased by $15 \%$ to $20 \%$ for the whole country with increase in monsoon and post-monsoon rainfall (particularly in eastern and central Nepal) as well as an increase in the intensity of rainfall, and a decrease in winter precipitation in the country (NCVST, 2009; OECD, 2003; FAO, 2010). Three decades meteorological parameters (1980-2010) as compared to the future Global Climate Data (GCM) indicated that the maximum temperatures will significantly increase the temperatures ranges $1.6-2.5^{\circ} \mathrm{C}$ while minimum temperatures also increases ranges from $1.1-1.9{ }^{\circ} \mathrm{C}$ in all five Global Climate Data (GCM). Due to the increment of both maximum and minimum temperatures, rainfed poor crops will be highly affected by the heat stress particularly on leaf firing, flower abortion, ste- rility problem and force maturity of rice and wheat and the rising temperatures favors more insects' incidences in the field which decreases the grain size and thereby grain yield. Similarly rainfall patterns also drastically reduce by almost $50 \%$ ( $815 \mathrm{~mm}$ per annum) than the current annual rainfall $1500 \mathrm{~mm}$ per annum. The rainfall data as compared to the future Global Climate Data (GCM) showed significantly reduce rains ranges from $194 \mathrm{~mm}$ to $5419 \mathrm{~mm}$; at that time farmers need to explore the alternate option i.e. deep boring tube well irrigation for farming the crops. Basically long duration cultivars are highly susceptible because these cultivars often need more water consumption but due to the reduction trends of rainfall and erratic type caused almost $20-30 \%$ yield reduce and again hue and cry situation develop in rainfed farming areas.

\section{Climate projections}

The climatic observations and projections therefore indicate that there will be increased climatic variability with more frequent extreme events (floods and droughts) with more likely substantial impacts on different sectors including agriculture in Nepal. Given the low development of the country with subsistence based, rainfed dominant farming system and complex topography, Nepal is highly vulnerable to climate change and managing agricultural risk associated with climate change and climate change adaptation is very challenging for the country (MoE, 2010). All five GCMs predicted higher mean monthly maximum and minimum temperatures during the mid-century period (2040-2069) under RCP8.5 compared to the baseline (1980-2010) (Figure 5). However, as far as rainfall projections are concerned, there are reduction trends in all GCM predictions except GCM IKXA (Figure 6). The crop growing season temperature and rainfall also showed in all the GCMs, especially precipitation change compared to baseline (Table 1). Since $79 \%$ of the total annual rainfall is received during the June to September monsoon season, a decrease of rainfall would affect the groundwater level and therefore require more energy to pump water.

\begin{tabular}{|c|c|c|c|c|c|}
\hline & $\begin{array}{c}\text { GCM } \\
\text { CCM4 } \\
\text { E }\end{array}$ & $\begin{array}{c}\text { GCM } \\
\text { GFDL-ESM2M } \\
\text { I }\end{array}$ & $\begin{array}{c}\text { GCM } \\
\text { HadGEM2-ES } \\
\text { K }\end{array}$ & $\begin{array}{c}\text { GCM } \\
\text { MIROC5 } \\
0\end{array}$ & $\begin{array}{c}\text { GCM } \\
\text { MPI-ESM-MR } \\
\text { R }\end{array}$ \\
\hline $\begin{array}{c}\text { Growing season temperature } \\
\text { change for wheat }\left({ }^{\circ} \mathrm{C}\right)\end{array}$ & 2.2 & 1.6 & 2 & 1.9 & 2.1 \\
\hline $\begin{array}{c}\text { Growing season precipitation } \\
\text { change for wheat (\%) }\end{array}$ & -70.6 & -172.4 & 45.4 & -6.3 & -50.3 \\
\hline $\begin{array}{l}\text { Growing season temperature } \\
\text { change for rice }\left({ }^{\circ} \mathrm{C}\right)\end{array}$ & 1.9 & 2.7 & 2.4 & 0.96 & 2.68 \\
\hline $\begin{array}{c}\text { Growing season precipitation } \\
\text { change for rice }(\%)\end{array}$ & 147 & -792 & 156.8 & -109.6 & -434.18 \\
\hline
\end{tabular}

Table 1: Climate changes for 2040-2070s compared to historical period for five targeted GCMs. 

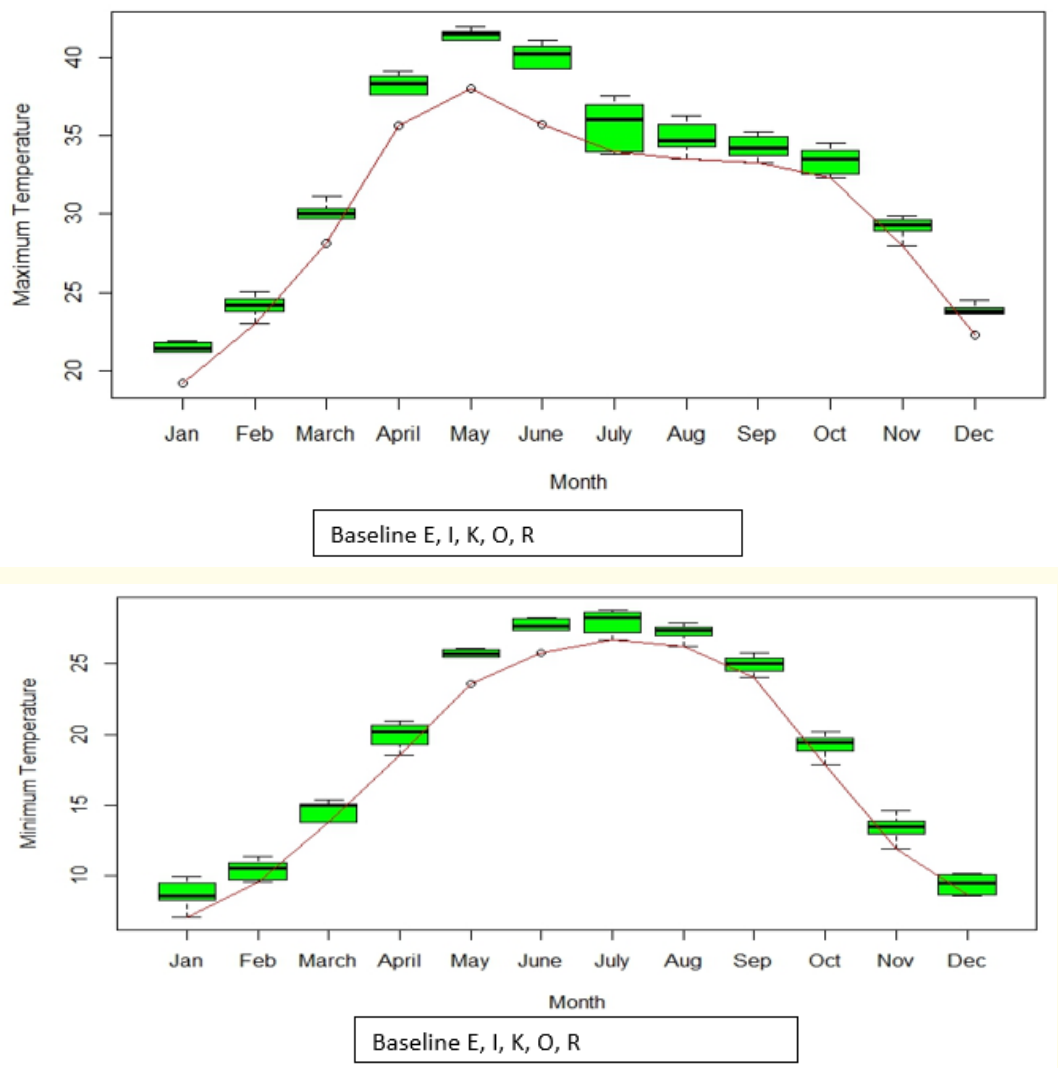

Figure 5: Baseline (line and dots) and future (box-and-whisker plots) monthly and seasonal mean maximum and minimum temperature for Nepalgunj, Banke district in the 2040-2070 under RCP8.5 for twenty GCMs. The stars represent the five GCMs (E-CCSM4, I-GFDL-ESM2M, K-HadGEM2-ES, O-MIROC5, and R-MPI-ESM-MR) used in the integrated assessment.

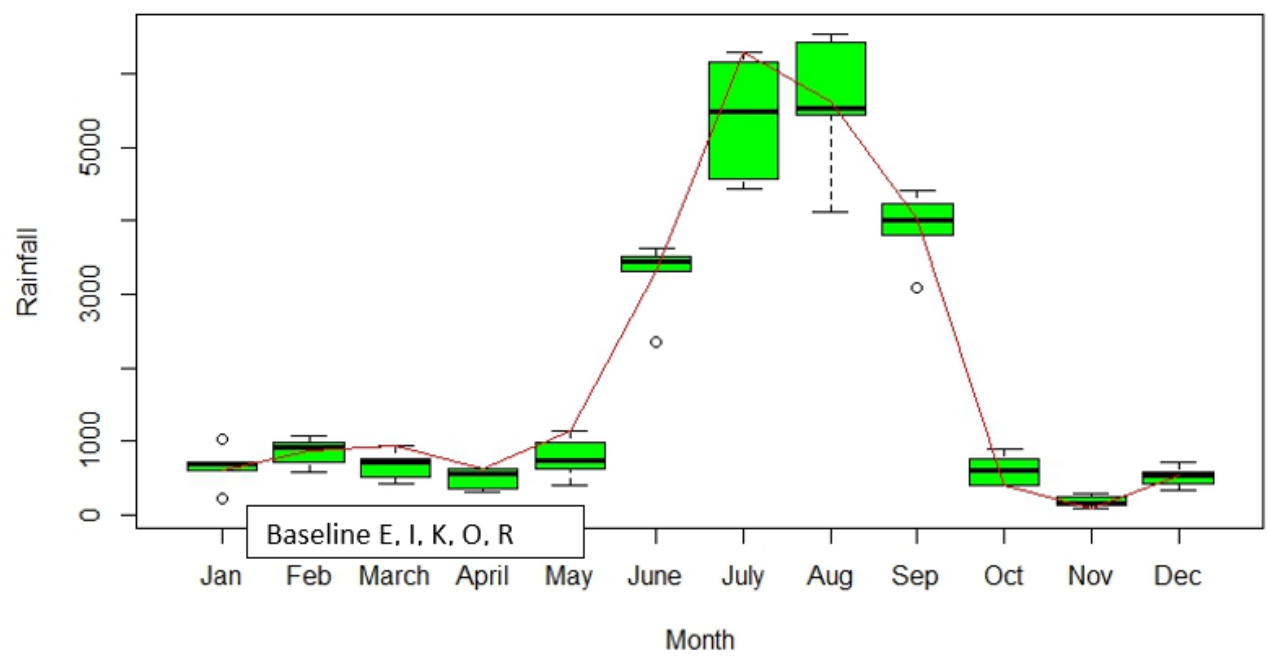

Figure 6: Baseline (line and dots) and future (box-and-whisker plots) monthly mean precipitation for Nepalgunj, Banke in the 2040-2070 under RCP8.5 for 20 GCMs. The stars represent the five GCMs (E-CCSM4, I-GFDL-ESM2M, K-HadGEM2-ES, 0-MIROC5, and R-MPI-ESM-MR) used in the integrated assessment. 


\section{Crops}

Crop-model calibration (DSSAT and APSIM)

The Agricultural Production Systems Simulator (APSIM) 7.5 crop model was already calibrated for the same rice and wheat varieties and the same. XML files were used for the AgMIP simulations. In the case of the Decision Support System for Agro-technology Transfer (DSSAT) 4.5, the genetic coefficients reported in Pathak., et al. (2003) for the same rice and wheat varieties were used.

\section{Crop model results (DSSAT and APSIM)}

Both APSIM and DSSAT simulated higher wheat yields compared to survey data after the cumulative probability level except one GCM (Figure 7). Since both crop models simulate yield without considering pest and diseases effects, the simulated yields are always higher than actual survey yield data. The differences in simulated wheat yield at higher and lower cumulative probability levels between APSIM and DSSAT may be due to the difference in sensitivity of the two crop models in extreme management situations. In the case of rice, both DSSAT and APSIM models overestimated yields compared to observed farm survey data. Moreover, DSSAT simulated higher rice yields than did APSIM. There is variability among the simulated impacts of climate change on rice and wheat by different GCMs and between the two crop models, DSSAT and APSIM (Figure 7). Differences between the DSSAT and APSIM projections are due to differences in sensitivity of the crop models to increases in $\mathrm{CO}_{2}$ and temperature. In the case of rice, out of the 20 GCMs there is a $80 \%$ positive response both in DSSAT-rice and wheat projected a pessimistic scenario. Overall, DSSAT simulated more optimistic projections than APSIM for wheat.
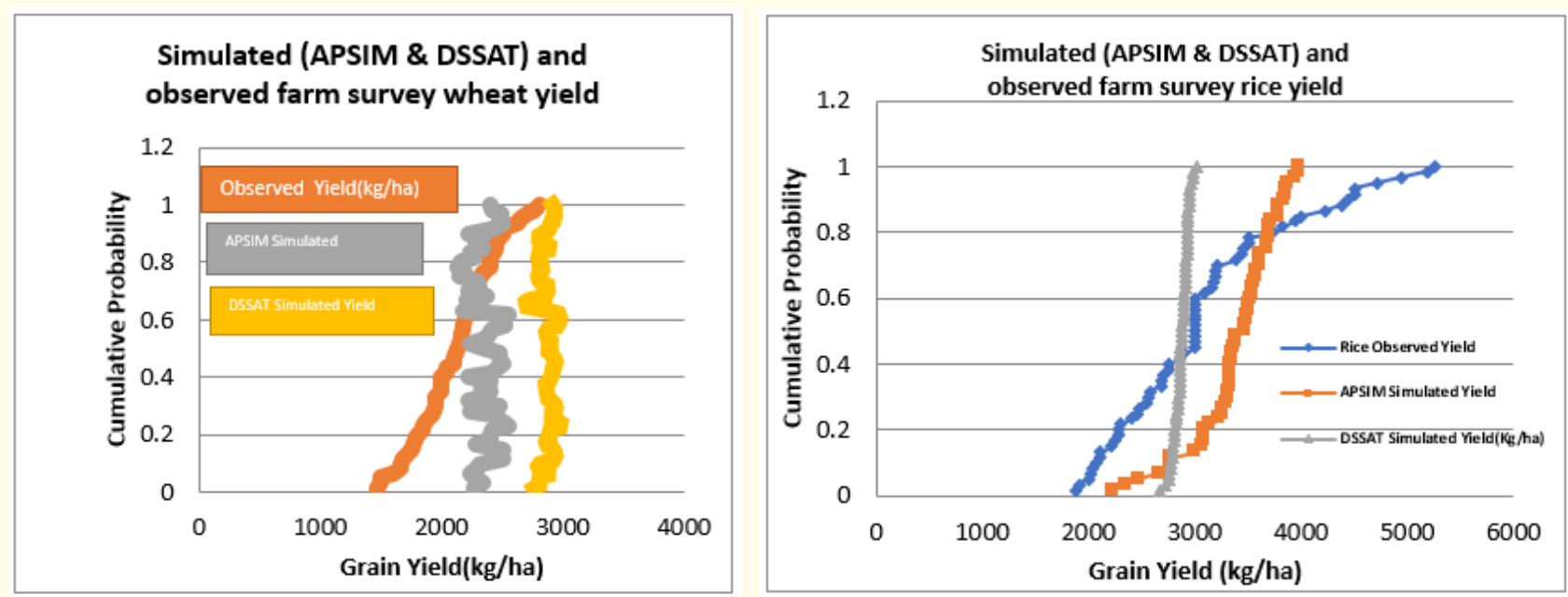

Figure 7: Cumulative distribution functions for observed farm survey wheat and rice yields, and APSIM and DSSAT simulated rice and wheat yields.

\section{Survey data}

This study used a secondary farm survey data obtained from Socio-Economics and Agricultural Research Policy Division (SARPOD) of Nepal Agricultural Research Council (NARC). SARPOD had conducted the household survey in Banke, Siraha and Tanahu districts of Nepal in 2008 under the 'Stress Tolerant Rice for Africa and South Asia (STRASA)' project of International Rice Research Institute (IRRI) which was implemented in collaboration with NARC in Nepal. SARPOD in 2008 had conducted this survey with about 100 farmers in two different VDCs (Puraina and Samshergunj) of Banke district and out of which survey data of 60 farms from were selected and used for this study. The survey data consists of demographic information, agricultural production and various socio-economic information and the relevant data from the samples were extracted for conducting this study.

\section{Parameters emerged from RAPs}

While developing RAPs, several parameters having plausible effect on the agricultural production system were identified and their direction and magnitude in the mid-century period were also estimated through the interaction with the stakeholders. Major parameters identified during preparing RAPs and used in TOA-MD simulation are presented in the table 2 below. 


\begin{tabular}{|l|c|c|}
\hline \multicolumn{1}{|c|}{ RAP Parameters } & $\begin{array}{c}\text { Direction of } \\
\text { Change }\end{array}$ & Magnitude \\
\hline Fertilizer price & Increase & $150 \%$ \\
\hline Seed price & Increase & $140 \%$ \\
\hline Rice, wheat, grain price & Increase & $155 \%$ \\
\hline Farm size & Decrease & $10 \%$ \\
\hline Family size & Decrease & $5 \%$ \\
\hline Labour availability & Decrease & $35 \%$ \\
\hline Wage rate & Increase & $160 \%$ \\
\hline Non-farm incomes & Increase & $60 \%$ \\
\hline CV of farm size and family size & Decrease & $20 \%$ \\
\hline CV of non-farm income & Decrease & $30 \%$ \\
\hline
\end{tabular}

Table 2: RAP parameters used in TOA-MD simulation.

Similarly growth trend in yield and prices of rice and wheat crop were obtained from IMPACT model. For estimating the yield and prices for rice and wheat crop for future period without climate change, AgMIP reference scenario of IMPACT model was used. Based on which, the yield and price trend used for rice crop was 1.25 and 1.19 respectively. Similarly, for wheat crop, yield and price trend used was 2.68 and 1.26 respectively. While for the price in the future period with climate change, SSP2_HGEM_ DSSAT_5crop scenario (IMPACT model) price was used. The price trend used for rice and wheat crop was 1.5 and 1.56 respectively for the future climate change scenario. Farmers were also growing mixed crops and the yield and price trend for the mixed crop were obtained assuming that they would change in line with rice and wheat crop. So, yield and price trend for mixed crop for the future period without climate change was assumed to be 1.50 and 1.25 respectively while price trend assumed for future period with climate change scenario was 1.5 .

\section{Adaptation package}

To reduce the climate change impacts, various adaptation packages were suggested by the stakeholders during stakeholder interactions. Major adaptation strategies suggested by the stakeholders and identified by various researches include

- Use of short duration, early maturing crop varieties

- Shifting of cropping pattern or advancement in sowing dates

- Use of balance fertilizers and irrigation

This study showed higher simulated yield of rice crop in the future period than the historic simulated yield (except in IIXA_APSIM where simulation results showed $18 \%$ decline in rice yield than the historic or based yield). This indicates that climate change will have positive impacts on rice production in rain-fed produc- tion environment. While, the study showed the declining future simulated yield of wheat crop than the historic simulated yield indicating a negative impact of climate change on wheat crop production. Therefore, adaptation strategy was applied in wheat crop to offset the loss due to climate change. Advancement of 20 days in seed sowing of wheat was the only adaptation strategy tested and used for this study.

Core Question 1: What is the Sensitivity of Current Agricultural Production Systems to Climate Change?

Impact of climate change on crop production

The integrated assessment result in DSSAT showed that mean yield of wheat crop in the future period would decline from $5 \%$ to $33 \%$ than the historic or base period. APSIM simulation also showed similar results for wheat with declining yield from $14 \%$ to $18 \%$ in the tested climate scenarios. In contrast to wheat, rice crop was found having higher mean yield in the future period than the base period and yield increase ranged from 11\% to 33\% in DSSAT and upto $21 \%$ in APSIM simulations. APSIM simulation interestingly also showed $18 \%$ yield decline in rice crop in the future period in GFDL ESM2M scenario. While for the mixed crops (which include crops like maize, lentil, chickpea, pigeon pea, mustard, and vegetables) an assumption was made that it would decline by $15 \%$ in all the climate scenarios in the future period. This assumption has been made based on the ground of various research reports reported by IFPRI and CCAFS in South Asia.

Economic impact of climate change on current production systems

Overall, the simulation results showed that the mean net farm returns would decline by $14 \%$ to $16 \%$ in DSSAT and $14 \%$ to $24 \%$ in APSIM in the tested climate scenarios. The simulation results in different climate scenarios have shown mixed results in per capita income (PCI), net farm returns and poverty rate. Both the crop model simulations (DSSAT and APSIM) have shown higher PCI, net farm returns and reduction in poverty in the future period in those scenarios where increase in rice yield is higher than decrease in wheat yield in future than the base period and vice versa. As the simulation results have shown both positive and negative effect of climate change in rice and wheat crop respectively, the results showed a very small difference (less than $1 \%$ ) in the poverty rate in between future and current period. DSSAT simulation has shown higher percentage of gainers (farm populations gaining in future period) in HadGEM2-ES, MIROC5, and MPI-ESM-MR scenarios while APSIM simulation has shown higher percentage of gainers CCSM4 and MIROC5 scenarios. Both the crop model simulations have shown higher percentage of losers in GFDL ESM2M scenario. 


\begin{tabular}{|c|c|c|c|c|c|c|c|c|c|c|}
\hline & \multicolumn{2}{|c|}{ CCSM4 (IEXA) } & \multicolumn{2}{|c|}{ GFDL ESM2M (IIXA) } & \multicolumn{2}{|c|}{$\begin{array}{l}\text { HadGEM2-ES } \\
\text { (IKXA) }\end{array}$} & \multicolumn{2}{|c|}{$\begin{array}{l}\text { MIROC5 } \\
\text { (IOXA) }\end{array}$} & \multicolumn{2}{|c|}{$\begin{array}{l}\text { MPI-ESM-MR } \\
\text { (IRXA) }\end{array}$} \\
\hline & DSSAT & APSIM & DSSAT & APSIM & DSSAT & APSIM & DSSAT & APSIM & DSSAT & APSIM \\
\hline \multicolumn{11}{|l|}{ Stratum 1} \\
\hline $\begin{array}{l}\text { Observed mean yield (rice) } \\
(\mathrm{kg} / \mathrm{ha})\end{array}$ & 2744 & 2744 & 2744 & 2744 & 2744 & 2744 & 2744 & 2744 & 2744 & 2744 \\
\hline $\begin{array}{l}\text { Mean yield change (rice) } \\
\text { (\%) [defined as: (mean } \\
\text { relative yield -1)*100] }\end{array}$ & 11 & 21 & 23 & -18 & 15 & 15 & 20 & 21 & 33 & 0 \\
\hline $\begin{array}{l}\text { Observed mean yield } \\
\text { (wheat) }(\mathrm{kg} / \mathrm{ha} \text { ) }\end{array}$ & 2417 & 2417 & 2417 & 2417 & 2417 & 2417 & 2417 & 2417 & 2417 & 2417 \\
\hline $\begin{array}{l}\text { Mean yield change (wheat) } \\
\text { (\%) [defined as: (mean } \\
\text { relative yield -1)*100] }\end{array}$ & -21 & -17 & -33 & -18 & -5 & -14 & -16 & -14 & -22 & -14 \\
\hline $\begin{array}{l}\text { Observed mean yield } \\
\text { (mixed crops) (kg/ha) }\end{array}$ & 1179 & 1179 & 1179 & 1179 & 1179 & 1179 & 1179 & 1179 & 1179 & 1179 \\
\hline $\begin{array}{l}\text { Mean yield change (mixed } \\
\text { crops) (\%) [defined as: } \\
\text { (mean relative yield } \\
\left.-1)^{*} 100\right]\end{array}$ & -15 & -15 & -15 & -15 & -15 & -15 & -15 & -15 & -15 & -15 \\
\hline Losers (\%) & 60.29 & 49 & 54.11 & 81.37 & 46.73 & 52.6 & 47.88 & 46.89 & 38.23 & 66.16 \\
\hline $\begin{array}{l}\text { Gains (\% mean net re- } \\
\text { turns) }\end{array}$ & 12.99421 & 15.1 & 14.31 & 10.6817 & 15.53 & 14.32 & 15.32 & 15.54 & 18.62 & 12.18 \\
\hline $\begin{array}{l}\text { Losses (\% mean net } \\
\text { returns) }\end{array}$ & -16.4704 & -14.7 & -15.72 & -23.8417 & -14.42 & -15.1901 & -14.59 & -14.48 & -14.18 & -17.79 \\
\hline $\begin{array}{l}\text { Observed net returns } \\
\text { without climate change } \\
\text { (Nepalese Rupees) }\end{array}$ & 20385 & 20385 & 20385 & 20385 & 20385 & 20385 & 20385 & 20385 & 20385 & 20385 \\
\hline $\begin{array}{l}\text { Observed net returns with } \\
\text { climate change (Nepalese } \\
\text { Rupees) }\end{array}$ & 19412 & 20492 & 19989 & 16838 & 20698 & 20139 & 20589 & 20684 & 21624 & 18825 \\
\hline $\begin{array}{l}\text { Observed per-capita } \\
\text { income without climate } \\
\text { change (Nepalese Rupees/ } \\
\text { person) }\end{array}$ & 14056 & 14056 & 14056 & 14056 & 14056 & 14056 & 14056 & 14056 & 14056 & 14056 \\
\hline $\begin{array}{l}\text { Observed per-capita in- } \\
\text { come with climate change } \\
\text { (Nepalese Rupees/person) }\end{array}$ & 13894 & 14074 & 13990 & 13466 & 14108 & 14015 & 14090 & 14106 & 14262 & 13796 \\
\hline $\begin{array}{l}\text { Observed poverty rate } \\
\text { without climate change } \\
\text { (\%) }\end{array}$ & 97.24 & 97.24 & 97.24 & 97.24 & 97.24 & 97.24 & 97.24 & 97.24 & 97.24 & 97.24 \\
\hline $\begin{array}{l}\text { Observed poverty rate } \\
\text { with climate change (\%) }\end{array}$ & 97.41 & 97.22 & 97.3 & 97.82 & 97.18 & 97.28 & 97.2 & 97.19 & 97 & 97.51 \\
\hline
\end{tabular}

Table 3: Climate Sensitivity.

Core Question 2: What is the Impact of Climate Change on Future Agricultural Production Systems?

Various RAP parameters and other estimates of productivity and price trends from a global model (IMPACT model) for rice and wheat crop and assumption of similar changes in yield and price of mixed crop was used in the TOA-MD analysis for assessing the impacts of climate change on future agricultural production systems. The simulation results have shown increasing yield of rice crop and 
Crop Model Simulation Slants for Predicting and Managing the Climate Risks in Poor Rainfed Rice-Wheat Eco-System of Mid-Western Nepal: Application of APSIM, DSSAT Model and Trade off Economic Analysis

declining yield of wheat crop and mixed crops in the future period than the base period. However, due to changes in the socio-economic parameters (increased output price), the simulation results have shown higher net farm returns, per capita income and reduc- tion in poverty rate in all the tested scenarios in the future period except in GFDL ESM2M scenario where DSSAT simulation results has shown decreasing net farm returns, per capita and income and slightly increased poverty rate in the future period than the base period.

\begin{tabular}{|c|c|c|c|c|c|c|c|c|c|c|}
\hline & \multicolumn{2}{|c|}{ CCSM4 (IEXA) } & \multicolumn{2}{|c|}{$\begin{array}{l}\text { GFDL ESM2M } \\
\text { (IIXA) }\end{array}$} & \multicolumn{2}{|c|}{$\begin{array}{l}\text { HadGEM2-ES } \\
\text { (IKXA) }\end{array}$} & \multicolumn{2}{|c|}{ MIROC5 (IOXA) } & \multicolumn{2}{|c|}{$\begin{array}{l}\text { MPI-ESM-MR } \\
\text { (IRXA) }\end{array}$} \\
\hline & DSSAT & APSIM & DSSAT & APSIM & DSSAT & APSIM & DSSAT & APSIM & DSSAT & APSIM \\
\hline \multicolumn{11}{|l|}{ Stratum 1} \\
\hline $\begin{array}{l}\text { Projected mean yield (rice) } \\
\text { (kg/ha) }\end{array}$ & 3457 & 3457 & 3457 & 3457 & 3457 & 3457 & 3457 & 3457 & 3457 & 3457 \\
\hline $\begin{array}{l}\text { Mean yield change (rice) (\%) } \\
\text { [defined as: (mean relative } \\
\text { yield -1)*100] }\end{array}$ & 11 & 21 & 23 & -18 & 15 & 15 & 20 & 21 & 33 & 0 \\
\hline $\begin{array}{l}\text { Projected mean yield (wheat) } \\
(\mathrm{kg} / \mathrm{ha})\end{array}$ & 6478 & 6478 & 6478 & 6478 & 6478 & 6478 & 6478 & 6478 & 6478 & 6478 \\
\hline $\begin{array}{l}\text { Mean yield change (wheat) } \\
\text { (\%) [defined as: (mean } \\
\text { relative yield }-1)^{*} 100 \text { ] }\end{array}$ & -21 & -17 & -33 & -18 & -5 & -14 & -16 & -14 & -22 & -14 \\
\hline $\begin{array}{l}\text { Projected mean yield (mixed } \\
\text { crops) (kg/ha) }\end{array}$ & 1769 & 1769 & 1769 & 1769 & 1769 & 1769 & 1769 & 1769 & 1769 & 1769 \\
\hline $\begin{array}{l}\text { Mean yield change (mixed } \\
\text { crops) (\%) [defined as: (mean } \\
\text { relative yield -1)*100] }\end{array}$ & -15 & -15 & -15 & -15 & -15 & -15 & -15 & -15 & -15 & -15 \\
\hline Losers (\%) & 41 & 31.89 & 56.89 & 47.07 & 19.97 & 29.42 & 29.46 & 28.08 & 33.06 & 33.27 \\
\hline Gains (\% mean net returns) & 16.85 & 19.84 & 13.43 & 15.18 & 27.65 & 20.94 & 21.16 & 21.57 & 19.73 & 19.15 \\
\hline Losses (\% mean net returns) & -13.7 & -12.94 & -15.74 & -14.2 & -12.94 & -12.82 & -12.97 & -12.75 & -13.25 & -12.93 \\
\hline $\begin{array}{l}\text { Observed net returns without } \\
\text { climate change (Nepalese } \\
\text { Rupees) }\end{array}$ & 49759 & 49759 & 49759 & 49759 & 49762 & 49759 & 49759 & 49759 & 49759 & 49759 \\
\hline $\begin{array}{l}\text { Observed net returns with } \\
\text { climate change (Nepalese } \\
\text { Rupees) }\end{array}$ & 51910 & 54428 & 48185 & 50430 & 59482 & 55236 & 55287 & 55698 & 54151 & 53977 \\
\hline $\begin{array}{l}\text { Observed per-capita in- } \\
\text { come without climate } \\
\text { change(Nepalese Rupees) }\end{array}$ & 24871 & 24871 & 24871 & 24871 & 24871 & 24871 & 24871 & 24871 & 24871 & 24871 \\
\hline $\begin{array}{l}\text { Observed per-capita income } \\
\text { with climate change (Nepalese } \\
\text { Rupees) }\end{array}$ & 25222 & 25633 & 24614 & 24980 & 26458 & 25765 & 25773 & 25840 & 25588 & 25559 \\
\hline $\begin{array}{l}\text { Observed poverty rate without } \\
\text { climate change (\%) }\end{array}$ & 71.17 & 71.17 & 71.17 & 71.17 & 71.17 & 71.17 & 71.17 & 71.17 & 71.17 & 71.17 \\
\hline $\begin{array}{l}\text { Observed poverty rate with } \\
\text { climate change (\%) }\end{array}$ & 70.47 & 68.65 & 71.99 & 70.82 & 65.93 & 68.21 & 68.17 & 67.97 & 68.77 & 60.9 \\
\hline
\end{tabular}

Table 4: Impact of climate in future without adaptation. 
Crop Model Simulation Slants for Predicting and Managing the Climate Risks in Poor Rainfed Rice-Wheat Eco-System of Mid-Western Nepal: Application of APSIM, DSSAT Model and Trade off Economic Analysis

Core Question 3: What Are the Benefits of Climate-change Adaptations?

Impact of adaptation on crop productivity

The simulation results showed both positive and negative effect of climate change to the rice and wheat crop yield respectively. Therefore, adaptation strategy was applied only for the wheat crop and advancement of seed sowing by 20 days was the key adaptation strategy applied to compensate the loss due to climate change.
DSSAT simulation results showed increase of wheat yield by $21 \%$ to $55 \%$ while APSIM showed $1 \%$ to $39 \%$ yield gain by adopting this adaptation strategy in wheat.

Impact of adaptation on farmers' livelihoods

The adaptation strategy is likely to result in an increase of mean net farm returns, per capita income and reduce the poverty rate of the farming population considerably.

\begin{tabular}{|c|c|c|c|c|c|c|c|c|c|c|}
\hline & \multicolumn{2}{|c|}{ CCSM4 (IEXA) } & \multicolumn{2}{|c|}{$\begin{array}{l}\text { GFDL ESM2M } \\
\text { (IIXA) }\end{array}$} & \multicolumn{2}{|c|}{$\begin{array}{l}\text { HadGEM2-ES } \\
\text { (IKXA) }\end{array}$} & \multicolumn{2}{|c|}{$\begin{array}{l}\text { MIROC5 } \\
\text { (IOXA) }\end{array}$} & \multicolumn{2}{|c|}{$\begin{array}{l}\text { MPI-ESM-MR } \\
\text { (IRXA) }\end{array}$} \\
\hline & DSSAT & APSIM & DSSAT & APSIM & DSSAT & APSIM & DSSAT & APSIM & DSSAT & APSIM \\
\hline \multicolumn{11}{|l|}{ Stratum 1} \\
\hline $\begin{array}{l}\text { Projected mean yield without } \\
\text { adaptation (rice) (kg/ha) }\end{array}$ & 3855 & 4168 & 4295 & 2844 & 3981 & 3968 & 4168 & 4188 & 4637 & 3472 \\
\hline $\begin{array}{l}\text { Mean yield change (rice) }(\%) \text { [defined } \\
\left.\text { as: (mean relative yield }-1)^{*} 100\right]\end{array}$ & 0 & 0 & 0 & 0 & 0 & 0 & 0 & 0 & 0 & 0 \\
\hline $\begin{array}{l}\text { projected mean yield without } \\
\text { adaptation (wheat) (kg/ha) }\end{array}$ & 5087 & 5369 & 4331 & 5295 & 6164 & 5577 & 5466 & 5562 & 5063 & 5576 \\
\hline $\begin{array}{l}\text { Mean yield change (wheat) (\%) [de- } \\
\left.\text { fined as: (mean relative yield }-1)^{*} 100\right]\end{array}$ & 55 & 18 & 55 & 34 & 44 & 39 & 21 & 5 & 25 & 1 \\
\hline $\begin{array}{l}\text { Projected mean yield without } \\
\text { adaptation (mixed crops) (kg/ha) }\end{array}$ & 1504 & 1504 & 1504 & 1504 & 1504 & 1504 & 1504 & 1504 & 1504 & 1504 \\
\hline $\begin{array}{l}\text { Mean yield change (mixed crops) } \\
(\%) \text { [defined as: (mean relative yield } \\
\left.-1)^{*} 100\right]\end{array}$ & 0 & 0 & 0 & 0 & 0 & 0 & 0 & 0 & 0 & 0 \\
\hline$\%$ adoption rate & 92.2 & 69.35 & 92.1 & 82.08 & 91.1 & 83.9 & 86.69 & 54.91 & 87.31 & 48.37 \\
\hline $\begin{array}{l}\text { Projected net returns without } \\
\text { adaptation(Nepalese Rupees) }\end{array}$ & 51936 & 54428 & 48191 & 50459 & 59491 & 55254 & 55287 & 55698 & 54107 & 53977 \\
\hline $\begin{array}{l}\text { Projected net returns with adaptation } \\
\text { (Nepalese Rupees) }\end{array}$ & 81412 & 62128 & 73028 & 62886 & 89633 & 70323 & 72426 & 60518 & 71368 & 57695 \\
\hline $\begin{array}{l}\text { Projected per-capita income without } \\
\text { adaptation (Nepalese Rupees) }\end{array}$ & 25226 & 25633 & 24615 & 24985 & 26459 & 25768 & 25773 & 25840 & 27155 & 25559 \\
\hline $\begin{array}{l}\text { Projected per-capita income with } \\
\text { adaptation (Nepalese Rupees) }\end{array}$ & 30036 & 26889 & 28668 & 27013 & 31378 & 28227 & 28570 & 26627 & 30145 & 26166 \\
\hline $\begin{array}{l}\text { Projected poverty rate without } \\
\text { adaptation (\%) }\end{array}$ & 69.99 & 68.65 & 71.98 & 70.81 & 65.93 & 68.21 & 68.17 & 67.97 & 63.51 & 68.9 \\
\hline $\begin{array}{l}\text { Projected poverty rate with } \\
\text { adaptation (\%) }\end{array}$ & 55.1 & 64.74 & 59.11 & 64.37 & 51.49 & 60.56 & 59.5 & 65.55 & 54.81 & 67.07 \\
\hline
\end{tabular}

Table 5: Adoption of adaptation package. 


\section{Conclusion}

The next steps would be sharing the results of this study to the stakeholders so that appropriate actions could be taken to reduce the impacts of climate change. Similarly, other adaptation strategies could also be tested to identify and ensure even better adaptation alternatives. Similarly, based on the knowledge and skill gained through this study, continuing the similar research incorporating livestock in other locations can also be another important next step.

\section{Bibliography}

1. MOAD. Statistical information on Nepalese Agriculture, Government of Nepal, Ministry of Agriculture Development, Nepal (2013).

2. Nelson GC., et al. "Climate Change Impact on Agriculture and Costs of Adaptation". International Food Policy Research Institute Washington, D.C (2009).

3. Thornton PK and Herrero M. "Climate change adaptation in mixed crop-livestock systems in developing countries". Global Food Security 9 (2014): 99-107.

\section{Volume 3 Issue 9 September 2019}

(C) All rights are reserved by Rajendra Darai., et al. 